\title{
Gambaran Perempuan dalam Dua Ilustrasi Online Jerman Bertema Weltfrauentag (Hari Perempuan Dunia)
}

\author{
Okta Mediutami Putri ${ }^{1}$, Lisda Liyanti ${ }^{1}$ \\ ${ }^{1}$ Program Studi Sastra Jerman, Fakultas Ilmu Pengetahuan Budaya, Universitas Indonesia, \\ Jalan Margonda Raya, Pondok Cina, Beji, Depok 16424 \\ Penulis untuk Korespondensi/E-mail : lisda.liyanti31@ui.ac.id
}

\begin{abstract}
Abstrak - Penelitian ini bertujuan untuk mengetahui bagaimana penggambaran perempuan setelah ditetapkannya Hari Perempuan Internasional (Weltfrauentag) dalam dua ilustrasi online yang dimuat pada dua portal ilustrasi online di Jerman, yaitu toonpool.de dan ce-comico.de. Metode penelitian yang digunakan berupa metode deskriptif kualitatif dengan pendekatan studi pustaka. Analisis ini menggunakan teori analisis wacana kritis model Sara Mills dan model teori segitiga semantik Charles Sanders Peirce. Hasil penelitian ini menunjukkan bahwa penggambaran perempuan dalam media baru berupa ilustrasi online menghadirkan diskusi terbuka mengenai pelekatan unsur domestik yang kuat pada perempuan. Diskusi ini dihadirkan oleh dua ilustrasi ini dengan cara berbeda. Ilustrasi pertama bernada positif, sedangkan yang kedua bernada pesimis. Ilustrasi pertama menggambarkan pelekatan unsur domestik melalui permainan kata oleh pemuka agama yang kemudian dipatahkan dengan penggunaan warna cerah dan simbol gambar yang mendukung kemajuan perempuan. Sementara itu, ilustrasi kedua menggunakan penggambaran relasi kuasa pada pimpinan laki-laki dan bawahan perempuannya. Kesadaran akan adanya hari perempuan dunia yang diucapkan pimpinan laki laki hanya mengacu pada kemampuan perempuan dalam mengerjakan pekerjaan domestik. Warna gelap dan simbol ada dalam gambar juga menyiratkan rasa pesimis yang diusung ilustrasi tersebut.
\end{abstract}

Abstract - The purpose of this research was to find out how the portrayal of women (concerning international women's day/Weltfrauentag) depicted in two German online illustrations. This research methodology is a qualitative method that is written by descriptive analysis with the approach of the study of literature. This research used Sara Mills's critical discourse analysis and semantic triangle theory by Charles Sanders Peirce. The research found that the portrayal of women in the new media (in the form of illustrated online) open the discussion on the domestication of woman. This discussion is presented differently in the two illustrations: while the first shows hope and positive attitude, the latter is seen pessimistic. The first illustration depicts the domestication of a woman using the word-play by two monks that are denied by using bright color and symbol of woman empowerment. The second illustration describes the power-relation between a male director and a woman employee. The male director argues the "International Woman Day" by referring only to woman domestic skills. The dark color and symbols support pessimistic attitude in the illustration.

Keywords - International Woman's Day, Domestication of Woman, online illustration, Weltfrauentag.

\section{PENDAHULUAN}

$\mathrm{S}$ ebagai negara dengan index gender equality yang seimbang (Hofstede), diskusi mengenai perempuan di Jerman menarik untuk dilihat. Dengan berkembang pesatnya gerakan feminisme banyak kemajuan yang di alami wanita di berbagai belahan dunia, terutama di Jerman yang saat ini dipimpin oleh seorang kaselir wanita. Hanya saja, dalam telaah lebih dalam, masih terdapat banyak penggambaran perempuan yang identik dengan berbagai macam stereotype. Hal ini karena konstruksi gender yang dibangun dalam konteks sosial budaya. Alfian Rokhmansyah menuliskan adanya stereotype yang menyebutkan bahwa "sifatnya yang feminisme, perempuan membutuhkan perlindungan dari laki-laki yang maskulin. Muncullah dominasi laki-laki terhadap perempuan baik dalam kehidupan berumah tangga maupun di dunia publik" [1]. Hal ini menyebabkan 
kedudukan perempuan seringkali dijadikan subordinat sedangkan laki-laki selalu digambarkan sebagai sosok yang lebih superior. Perempuan hanya memiliki fungsi sebagai seorang istri, seorang pengasuh yang bertugas menjaga anak-anaknya dan seorang pembantu yang harus mengurusi keperluan rumah tangga lainnya. Representasi perempuan yang identik unsur domestik seperti sapu dan alat keperluan rumah tangga dapat terlihat pada beberapa iklan-iklan peralatan rumah tangga di Jerman yang selalu menggunakan sosok perempuan yang selalu disandingkan dengan berbagai macam unsur domestik, yaitu alat masak atau peralatan kebersihan pada tahun 1960an. Iklan yang dibuat merujuk kepada pemahaman bahwa tugas perempuan memang hanya sekedar memasak dan membersihkan rumah. Perempuan dalam media terus menerus digambarkan dalam stereotype yang membatasi persepsi dirinya di dalam masyarakat [2].

Representasi terhadap perempuan yang selalu diidentikkan dengan alat-alat domestik pada media massa tersebut, tentu menimbulkan pergerakan perempuan (feminisme) yang berusaha untuk mencapai kesetaraan gender. Hingga akhirnya pada tanggal 8 Maret 1978 menjadi tolak ukur perempuan untuk mendapatkan hak-haknya karena Perserikatan Bangsa Bangsa (PBB) menetapkan tanggal tersebut sebagai Hari Perempuan Internasional. Salah satu hak perempuan Jerman yang didapatkan setelah adanya hari Perempuan Internasional adalah dapat mengikuti pemilihan umum. Hal ini juga telah tercantum dalam paragraf pertama Artikel 38 Konstitusi Jerman Grundgesetz bahwa semua warga Jerman baik perempuan maupun laki-laki yang berusia diatas 18 tahun berhak memberikan suara, tidak bergantung pada harta, tingkat pendidikan dan keyakinan politiknya [3]. Namun, penggambaran perempuan dalam media massa pun turut mengikuti perubahan seiring dengan konstruksi masyarakatnya, begitupun dengan media baru yang sekarang lebih sering diakses oleh masyarakat. Penggunaan platform baru yang melibatkan internet dalam mengakses informasi memunculkan karakteristik baru dalam masyarakat, yaitu keleluasaan masyarakat untuk memilih informasi apa yang diperlukan. Berdasarkan survei yang dilakukan oleh Center for Strategic and International Studies (CSIS) pada tahun 2017 dengan tajuk "Orientasi Sosial, Ekonomi dan Politik Generasi Milenial" menunjukkan bahwa media online menjadi sumber informasi favorit bagi generasi milenial [4]. Hal ini turut membuktikan bahwa masyarakat sekarang ini lebih tertarik untuk mengakses informasi melalui media online seperti website berita. Salah satu alasan generasi milenial menggunakan media online karena sisipan foto, gambar dan konten visual yang lebih menarik sehingga tidak membosankan seperti media cetak.

Isu-isu yang ditampilkan dalam media online berkaitan dengan permasalah sosial maupun politik yang cukup berat, namun disajikan dengan cara yang bersifat menghibur seperti ilustrasi online, gambargambar kartun dan meme-cuplikan gambar dari acara televisi, film, dan sebagainya atau gambargambar buatan sendiri yang dimodifikasi dengan menambahkan kata-kata atau tulisan-tulisan untuk tujuan melucu dan menghibur [5]. Salah satu isu sosial yang selalu mengalami perkembangan seiring dengan perubahan konstruksi dalam masyarakat adalah isu gender. Meskipun medium yang digunakan berbeda tapi fokus isu gender masih tertuju pada sosok perempuan. Bagaimana perempuan digambarkan dalam media online terutama ilustrasi online. Penelitian ini berusaha menganalisis bagaimana perempuan digambarkan dalam media online terutama ilustrasi online. Melalui analisis terhadap representasi perempuan dalam media online dapat terlihat pula bagaimana konstruksi sosial masyarakat yang berkembang dalam melihat perempuan dalam kurun waktu tertentu.

Penelitian mengenai penggambaran terhadap perempuan dalam media cetak sudah pernah dilakukan oleh Jaworska, S., \& Krishnamurthy, R. dalam artikel jurnal berjudul On the F word: A Corpus-based Analysis of The Media Representation of Feminism in British and German Press Discourse 1990-2009. Artikel tersebut menjelaskan bahwa sebagian besar wacana feminis yang diterbitkan oleh media massa Jerman di tahun 1990-2009 berkaitan dengan kepentingan pergerakan suatu politik tertentu (sosialismus-komunismus). Ada beberapa kata rujukan terkait dengan gender, seperti penggunaan kata Frau (perempuan), Mann (lakilaki), Geschlecht (gender). Adanya dominasi (relasi kuasa) dari kepentingan suatu golongan turut membentuk konstruksi media massa dalam menggambarkan sosok perempuan. Penelitian Jaworska, S., \& Krishnamurthy, R tersebut memiliki hubungan dengan penelitian ini dan diajukan sebagai acuan pembanding penggambaran perempuan dalam media klasik di Jerman selama 10 tahun terakhir karena ilustrasi online yang digunakan pada penelitian ini bersumber dari media massa Jerman [6]. Atribut yang disampaikan oleh Jaworska, S., \& Krishnamurthy, R berupa kata "Frau" yang 
mempengaruhi keefektifan maksud dari wacana akan dikaji lebih lanjut dalam penelitian ini.

Jurnal kedua yang turut membahas mengenai penggambaran perempuan dan media massa adalah Representasi Wanita Dalam Media Massa Masa Kini yang ditulis oleh Errika Dwi Setya Watie dalam jurnal THE MESSENGER, Volume II, Nomor 2, Edisi Juli 2010. Dalam artikel tersebut dijelaskan bahwa perempuan sudah mulai mendapatkan hak yang setara dengan laki-laki dalam dunia nyata. Meskipun demikian penggambaran perempuan dalam media massa kini baik cetak dan online masih belum dapat terlepas dari stereotype yang berkaitan dengan kewajiban memasak, menata rumah dan merawat anak. Dalam media baru berupa iklan kecantikan, perempuan identik dengan kegiatan merawat tubuh dan mempertahankan kecantikannya melalui simbol atau tanda tertentu demi menarik perhatian laki-laki [7]. Analisis yang dilakukan oleh Errika Dwi Setya Watie pada jurnal tersebut memiliki keterkaitan dengan jurnal ini karena adanya analisis simbol atau tanda untuk mengetahui rujukan terhadap perempuan dalam realitas sosial.

Dalam artikel ini, akan dipaparkan analisis wacana gender dalam dua ilustrasi online Jerman yang berkaitan dengan Hari Perempuan Internasional (dalam bahasa Jerman Weltfrauentag). Bagaimana perempuan digambarkan dalam masyarakat pada saat ini, adakah perbedaan penggambaran perempuan dalam media online dengan media klasik selama satu dekade terakhir menjadi fokus bahasan. Dua portal ilustrasi online ce-comico.de dan toonpool.de dipilih karena merupakan komunitas kartun dan karikatur online terbesar di Jerman. Untuk toonpool.de bahkan dikatakan sebagai yang terbesar di dunia dengan 279.539 gambar dari 3.225 seniman di 120 negara [8]. Kedua ilustrasi yang digunakan sebagai korpus data dipublikasikan dalam waktu yang berbeda. Ilustrasi pertama yang berasal dari portal ilustrasi ce-comico.de dibuat pada tahun 2010, sedangkan ilustrasi online berasal portal ilustrasi toonpool.de dibuat pada tahun 2012. Perbedaan tahun publikasi kedua ilustrasi dianggap ideal untuk menunjukkan bagaimana penggambaran perempuan dalam konstruksi masyarakat saat itu. Dengan demikian, dapat terlihat apakah penggambaran perempuan dalam ilustrasi online hingga saat ini berubah secara signifikan atau perlahan.

\section{METODE}

Metode penelitian yang digunakan berupa metode deskriptif kualitatif. Tujuan dari metode deskriptif kualitatif adalah menggambarkan suatu kondisi dan fenomena sosial yang ada di masyarakat terkait dengan ilustrasi online yang digunakan. Pendekatan yang dilakukan berupa studi kepustakaan dengan mengumpulkan informasi yang relevan terhadap masalah yang akan diteliti. Informasi tersebut diperoleh melalui buku-buku ilmiah atau sumbersumber tertulis baik cetak maupun elektronik yang ada kaitannya dengan penelitian serta penelitianpenelitian yang pernah dilakukan sebelumnya. Selain itu pendekatan mimetik juga digunakan untuk melihat realitas yang ada di masyarakat. Apa karya yang digambarkan dalam karya sastra merupakan refleksi dari kenyataan yang terjadi pada waktu tersebut [9].

Data yang digunakan adalah dua ilustrasi online bertema Weltfrauentag (Hari Perempuan Dunia) yang bersumber dari laman Ce-comico.de dan toonpool.com. Ilustrai online berupa gambar, simbol dan tulisan dari tokoh dalam ilustrasi online ini akan dianalisa berdasarkan teori-teori yang mendukung. Salah satu teori yang digunakan adalah teori gender. Gender sering dihubungkan dengan pembahasan mengenai pembagian peran serta tanggung jawab baik laki-laki maupun perempuan yang dikonstruksikan oleh masyarakat dan budaya. Proses penguatan isu gender dapat terbentuk melalui interaksi dalam masyarakat seperti sosialisasi, kebudayaan dan bahkan ke dalam kekuasaan negara. Gender merupakan salah satu faktor penting dalam penindasan terhadap kelompok lain. Penindasan dapat dilihat melalui perbandingan penggambaran tokoh laki-laki dan perempuan dalam suatu teks. Kemudian gender mempertahankan wacana bahwa adanya perbedaan peran sosial antara laki-laki dan perempuan yang didasarkan hanya pada jenis kelaminnya [10].

Analisis wacana yang dilakukan menggunakan model analisis wacana milik Sara Mills sebagai acuan. Teks yang dimaksud bukan hanya sekedar naskah pidato, buku atau artikel dalam surat kabar, melainkan semua jenis ekspresi komunikasi lain seperti film, musik, gambar atau ilustrasi. Model analisis wacana Sara Mills berfokus pada bagaimana 
sebuah teks dalam merepresentasikan perempuan. Pendekatan yang coba digunakan berfokus kepada dua posisi, yaitu posisi subjek-objek dan posisi penulis-pembaca. Melalui pendekatan tersebut, dapat dijabarkan bagaimana posisi subjek-objek dalam sebuah teks dan posisi penulis-pembaca yang kemudian posisi-posisi tersebut dapat menentukan bagaimana struktur dan makna teks secara keseluruhan. Dalam jurnal ini, teks yang dimaksud mengacu pada ilustrasi online yang berasal dari Jerman. Selain kedua posisi yang telah disebutkan sebelumnya analisis wacana kritis model Sara Mills juga menunjukkan bahwa media memiliki peran penting dalam mengkonstruksikan wacana yang disampaikan kepada pembaca. Media dianggap sebagai sebagai agen kontruksi sosial yang mendefinisikan realitas sesuai dengan kepentingannya [11].

Teori yang digunakan selanjutnya adalah teori segitiga semantik milik Charles Sanders Peirce. Semiotika merupakan salah satu disiplin ilmu yang memungkinkan seseorang untuk memberikan makna pada apa yang ditampilkan oleh tanda. Tanda yang dimaksud dapat berupa gambar dan warna. Melalui segitiga semantik, seseorang mampu menghubungkan antara konsep/ interpretant, acuan/object dan tanda/sign [12].

Konsep berkaitan dengan suatu makna tertentu atau makna yang ada dalam benak seseorang tentang objek yang ditujuk sebuah tanda. Objek atau acuan tanda adalah konteks sosial yang menjadi referensi dari tanda atau sesuatu yang dirujuk tanda. Dalam analisis, teori ini digunakan untuk melihat konsep dari gambar dan warna (objek) yang terdapat dalam ilustrasi online dengan konteks sosial (referensi). Warna juga merupakan proses semiotis yang sudah menjadi tanda budaya dalam masyarakat. Berbagai konsep warna telah dikaitkan dengan budaya yang merepresentasikan pandangan atau cara berpikir masyarakat [13].

Melalui teori-teori yang telah dijelaskan diatas dilakukan analisa terhadap kedua ilustrasi online tentunya untuk mengetahui bagaimana perempuan dipandang setelah ditetapkannya Hari Perempuan Internasional dalam dua ilustrasi online Jerman yang dimuat pada dua portal ilustrasi online di Jerman, yaitu toonpool.de dan ce-comico.de.

\section{HASIL DAN PEMBAHASAN}

\section{Permainan Kata dan Pelekatan Unsur Domestik Pada Feminism dalam Ilustrasi ce-comico.de}

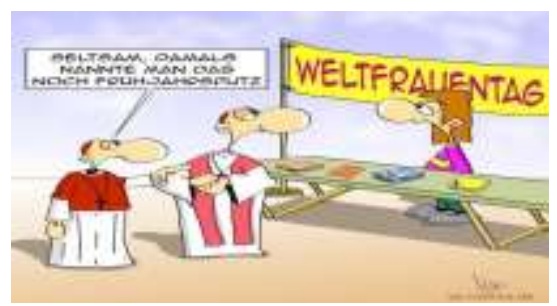

Gambar 1. Ilustrasi Am 8. März ist Weltfrauentag

(8 Maret adalah Hari Perempuan Dunia) [14]

Ce-comico.de merupakan salah satu portal ilustrasi dan kartun online di Jerman. Melalui website cecomico.de pembaca dapat melihat berbagai jenis ilustrasi online dengan tema yang berbeda-beda dari beragam ilustrator atau karikatur Jerman. Ilustrasi diatas mulai dipublikasi pada tahun 2010, namun tidak dijelaskan dengan rinci siapa ilustratornya. Namun hak cipta dari ilustrasi ini dimiliki oleh Marcus Gottfried yang pada saat itu turut aktif menyumbangkan karyanya pada website cecomico.de. Tema dalam ilustrasi diatas berkaitan dengan wacana perempuan dalam pendidikan serta penggambaran perempuan yang sesuai dengan dogma agama tertentu.

Dalam ilustrasi berjudul Am 8. März ist Weltfrauentag (8 Maret adalah Hari Perempuan Dunia) diatas terdapat tiga tokoh yang terlibat, yaitu dua orang pastor dan seorang perempuan. Berdasarkan model analisis wacana kritis feminis Sara Mills terlihat bahwa subjek pada ilustrasi diatas ini adalah kedua pastor yang mengutarakan pendapatnya mengenai perempuan sekarang. Perempuan dalam ilustrasi diatas masih dianggap sebagai objek yang diperbincangkan. Wacana yang berusaha disampaikan melalui ilustrasi ini berkaitan dengan stereotype perempuan yang telah berkembang khususnya bagi penganut agama katolik. Melihat kembali pada kondisi perempuan pada saat abad pertengahan di Jerman, perempuan memiliki tiga fungsi utama 3K (Kirche/Gereja, Kuche/Dapur und Kinder/Anak) [11]. Perempuan hanya memiliki fungsi domestik meliputi fungsi reproduksi, fungsi mengurus semua kebutuhan keluarga berupa makanan ataupun kebersihan rumah dan mengajarkan agama kepada anak-anak sehingga menjadi pribadi yang baik. Wacana tersebut berkembang karena kuatnya pemahaman masyarakat luas mengenai perempuan yang hanya memiliki ketiga fungsi tersebut. 
Selain itu, dogma agama Katolik bersifat fundamental pada segala bidang kehidupan masyarakat pada abad pertengahan. Pada abad pertengahan, gereja memiliki relasi kuasa tertinggi dalam mengatur kehidupan masyarakat. Dengan demikian, penggambaran kedua pastor dalam ilustrasi tersebut menunjukkan bagaimana peran perempuan yang sesuai dengan agama Katolik dan perubahannya dengan peran perempuan sekarang. Perempuan yang sesuai dengan agama Katolik hanya memiliki kewajiban untuk mengurus rumah tangga dan mengajarkan agama pada keluarganya. Namun sekarang ini, perempuan sering kali bekerja untuk dapat memenuhi kebutuhan anggota keluarganya. Seorang istri tidak hanya menjalani perannya sebagai ibu rumah tangga saja, melainkan membantu suami mencari nafkah. Dengan demikian, tanggung jawab yang harus dilaksanakan istri semakin bertambah, tanggung jawab menjadi ibu rumah tangga dan tanggung jawab pekerjaan [15]. Pernyataan tersebut dapat dibuktikan melalui survei yang dilakukan oleh Organisasi Buruh Internasional (ILO) yang mencatat bahwa pertumbuhan jumlah pekerja perempuan meningkat setiap tahunnya. Pada tahun 2015, 38\% dari 120 juta pekerja di Indonesia adalah perempuan [16].

Faktor lain yang menunjukkan keterkaitan antara penetapan Weltfrauentag dengan dogma agama terdapat pada kata Frühjahrsputz dalam kalimat yang dikatakan oleh salah satu pastor pada ilustrasi diatas, yaitu

\section{"seltsam, damals nannte man das noch Frühjahrsputz"}

memiliki arti dalam bahasa Indonesia berupa

$$
\begin{gathered}
\text { "Aneh, waktu itu dikenal sebagai kegiatan bersih- } \\
\text { bersih pada musim semi" }
\end{gathered}
$$

Frühjahrsputz dikenal sebagai salah satu tradisi "bersih-bersih" rumah yang dilakukan oleh keluarga di Jerman. Kegiatan "bersih-bersih" tersebut dilakukan setiap awal tahun di bulan Februari atau Maret di saat musim semi. Seperti yang kita tahu bahwa Hari Perempuan Internasional juga ditetapkan pada bulan Maret hampir bersamaan dengan kegiatan pembersihan di musim semi. Oleh karena itu, hari yang menjadi tolak ukur perempuan di seluruh dunia untuk mendapatkan kesetaraan masih saja terkait dengan wacana peran perempuan sejak abad pertengahan khususnya membersihkan rumah. Selain itu asal usul dari tradisi Frühjahrsputz juga dihubungkan dengan tradisi yang berlangsung dari zaman Romawi kuno mengenai ritual untuk pembersihan diri atau pertobatan pada awal musim semi yang dilakukan oleh pihak gereja Katolik. Berdasarkan hasil Konferensi Umum yang bertemakan Menemukan Sukacita Melalui Pelayanan Kasih menunjukkan bahwa pelayanan serta pemanggilan yang dilakukan gereja bertujuan untuk memberikan perlambangan akan harapan baru di awal musim semi, di tengah-tengah kesibukan dalam menjalani berbagai macam tuntutan hidup, seperti pendidikan, pekerjaan, membesarkan anak dan kegiatan duniawi lainnya yang membuat seorang umat merasa lelah.

Selanjutnya penggunaan bentuk lampau dalam kalimat "seltsam, damals nannte man das noch Frühjahrsputz" mampu menunjukkan bahwa wacana gender terhadap perempuan mengenai tiga fungsi perempuan sudah menjadi sesuatu yang sudah lama terjadi dan mengindikasi adanya perubahan pada kondisi sekarang ini. Wacana gender perempuan mengalami peningkatan dalam ilustrasi diatas dengan adanya gambar buku-buku yang berada diatas meja sehingga pada ilustrasi tersebut perempuan juga mendapatkan porsi untuk menunjukkan kehadirannya.

Berdasarkan model analisis semiotika Peirce, buku dapat dikatakan sebagai sebuah ikon atau tanda yang muncul dari perwakilan fisiknya. Kemudian acuan tanda (objek) yang dirujuk tentunya dapat merujuk kepada wawasan, pengetahuan dan pendidikan. Bila dikaitkan dengan realitas sosial sekarang ini terlihat bahwa seorang perempuan juga memiliki hak untuk memperoleh pengetahuan melalui pendidikan layaknya laki-laki. Berbeda dengan pada abad pertengahan, hanya laki-laki dan perempuanperempuan bangsawan yang memiliki akses bebas untuk memperoleh pendidikan. Selain buku, kebebasan dalam memperoleh pendidikan bagi sosok perempuan juga dapat dilihat dari pemilihan warna pada ilustrasi yang cenderung cerah dan didominasi oleh warna putih.

Dalam makalah akhir yang dibuat oleh Yuliyanah Sain diterangkan bahwa warna putih dapat diasosiasikan sebagai sebuah bentuk kebebasan. Berbeda dengan asosiasi warna putih pada zaman Romawi kuno, yaitu sebagai tanda kemenangan dan hari-hari yang bermanfaat ditandai pada kalender dengan kapur putih [17]. Dalam ilustrasi di atas, warna putih yang diartikan sebagai tanda kebebasan yang didapatkan sosok perempuan sekarang dalam memperoleh wawasan melalui proses pendidikan. Bila dikaitkan dengan kondisi sekarang, perempuan 
memiliki hak dalam memperoleh pendidikan yang setara dengan laki-laki.

Berdasarkan analisis yang sudah dijelaskan sebelumnya, dapat dikatakan bahwa wacana yang coba disampaikan melalui ilustrasi diatas berkaitan dengan salah satu fungsi domestik perempuan, yaitu melakukan kegiatan bersih-bersih. Pernyataan tersebut dapat dibaca pada ucapan para pendeta kepada tokoh perempuan. Permainan kata dengan menyamakan Frühjahrsputz dengan Weltfrauentag menjadi strategi utama yang digunakan oleh para pendeta kepada tokoh perempuan. Dalam ilustrasi di atas terlihat ada dua posisi yang saling berhadapan, yaitu seorang perempuan dengan dua orang pendeta. Namun dengan penambahan simbol berupa buku yang berada di depan tokoh perempuan dan warna dasar dari ilustrasi diatas mampu memberikan pemaknaan yang positif terhadap penggambaran sosok perempuan dalam ilustrasi diatas. Buku dapat merujuk kepada hak perempuan untuk mendapatkan pendidikan. Hal ini didukung dengan penggunaan warna yang terang memberikan nuansa yang lebih positif terhadap posisi perempuan. Selain itu, tulisan yang terdapat pada sebuah spanduk dengan kata Weltfrauentag juga mampu memperkuat posisi perempuan dan menegasikan kata Frühjahrsputz yang diucapkan kedua pendeta.

Tabel 1. Alur analisa ilustrasi:

\begin{tabular}{|c|c|c|}
\hline Tanda & Acuan Tanda & $\begin{array}{l}\text { Interpretasi } \\
\text { makna }\end{array}$ \\
\hline $\begin{array}{l}\text { Gambar buku } \\
\text { dan } \\
\text { perempuan } \\
\text { penjaga buku } \\
\text { lberupa ikon } \\
\text { yang muncul } \\
\text { sebagai } \\
\text { perwakilan } \\
\text { fisiknya. }\end{array}$ & $\begin{array}{lr}\text { Merujuk } & \text { pada } \\
\text { wawasan, } & \\
\text { pengetahuan, dan } \\
\text { pendidikan } & \text { yang } \\
\text { dimiliki } & \text { atau } \\
\text { dijaga } & \text { oleh } \\
\text { perempuan } & \end{array}$ & $\begin{array}{l}\text { Bahwa } \\
\text { seorang } \\
\text { perempuan } \\
\text { juga } \\
\text { memiliki hak } \\
\text { untuk } \\
\text { memperoleh } \\
\text { pengetahuan } \\
\text { melalui } \\
\text { pendidikan }\end{array}$ \\
\hline $\begin{array}{l}\text { Dua Pendeta } \\
\text { mengucapkan } \\
\text { Frühjahrsputz }\end{array}$ & $\begin{array}{l}\text { Ajaran agama, } \\
\text { terkait dengan } \\
\text { nilai nilai } \\
\text { keagamaan dan } \\
\text { pandangannya } \\
\text { terhadap } \\
\text { perempuan }\end{array}$ & $\begin{array}{l}\text { Bahwa } \\
\text { dogmatisasi } \\
\text { agama } \\
\text { menekankan } \\
\text { peran } \\
\text { perempuan } \\
\text { pada ranah } \\
\text { domestik }\end{array}$ \\
\hline $\begin{array}{l}\text { Perkataan } \\
\text { Frühjahrsputz } \\
\text { VS tulisan } \\
\text { Weltfrauentag }\end{array}$ & $\begin{array}{l}\text { Merujuk pada dua } \\
\text { hal yang sama } \\
\text { (terkait } \\
\text { perempuan,diperi }\end{array}$ & $\begin{array}{l}\text { Permainan } \\
\text { kata yang } \\
\text { mencermink } \\
\text { an }\end{array}$ \\
\hline
\end{tabular}

\begin{tabular}{|c|c|c|}
\hline Tanda & Acuan Tanda & $\begin{array}{c}\text { Interpretasi } \\
\text { makna }\end{array}$ \\
\hline $\begin{array}{l}\text { yang } \\
\text { ditampilkan } \\
\text { bersebrangan }\end{array}$ & $\begin{array}{l}\text { ngari pada bulan } \\
\text { Maret), sekaligus } \\
\text { bertentangan. } \\
\text { Frühjahrsputz } \\
\text { yang sangat terkait } \\
\text { domestikasi } \\
\text { perempuan, dan } \\
\text { Weltfrauentag } \\
\text { yang berasosiasi } \\
\text { pada pembebasan } \\
\text { perempuan dari } \\
\text { (hanya) ranah } \\
\text { domestic. }\end{array}$ & $\begin{array}{l}\text { pertentangan } \\
\text { dan } \\
\text { perjuangan } \\
\text { perempuan } \\
\text { untuk keluar } \\
\text { dari ranah } \\
\text { domestic } \\
\text { selalu } \\
\text { mendapat } \\
\text { tantangan } \\
\text { dan } \\
\text { perdebatan. }\end{array}$ \\
\hline Warna cerah & $\begin{array}{l}\text { Merujuk pada hal } \\
\text { baik dan terang }\end{array}$ & $\begin{array}{l}\text { Bahwa } \\
\text { perjuangan } \\
\text { perempuan } \\
\text { memiliki } \\
\text { harapan dan } \\
\text { masa } \\
\text { depanyang } \\
\text { baik }\end{array}$ \\
\hline
\end{tabular}

\section{Relasi Kuasa dan Pelekatan Unsur Domestik Pada Feminism dalam Ilustrasi toonpool.com}

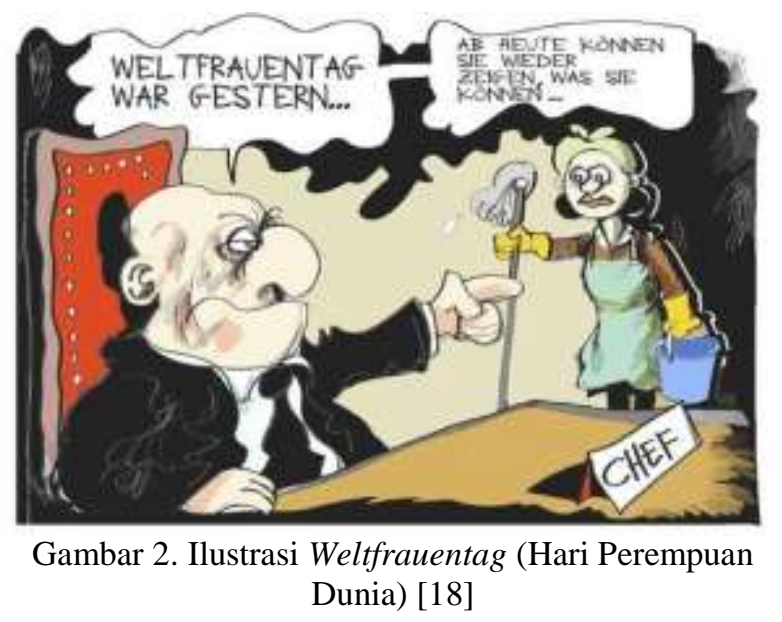

Toonpool.com merupakan salah satu portal hiburan online untuk seseorang melihat berbagai jenis karya dalam bentuk kartun. Website toonpool.com dapat diakses dari 120 negara dan telah memperlihatkan hasil kartun lebih dari 2500 kartunis. Meskipun Toonpool.com bukanlah website resmi yang dibuat di Jerman, namun ada beberapa kartunis yang membuat kartunnya dalam bahasa Jerman seperti Kostas Koufogiorgos. Ilustrasi kedua dibuat oleh Kostas Koufogiorgos yang merupakan salah satu kartunis dari Yunani. Meskipun tidak berasal dari Jerman, beliau turut berkontribusi sebagai salah satu kartunis di Jerman. Hal ini terbukti pada saat tahun 
2012, ia berhasil mendapatkan salah satu penghargaan Jerman terkait dengan kartun bertemakan politik yang dibuatnya. Hingga saat ini ia masih tetap aktif menjadi salah satu ilustrator di beberapa surat kabar dan majalah terkenal di Jerman [19].

Serupa dengan dengan ilustrasi yang sudah dijelaskan sebelumnya, ilustrasi kedua yang berjudul Weltfrauentag (Hari Perempuan Dunai) juga memperlihatkan oposisi perempuan dan lakilaki, dalam hal ini seorang perempuan dengan pimpinan laki-lakinya. Hal ini dapat terlihat dari papan jabatan yang bertuliskan Chef yang memiliki arti pimpinan perusahaan dalam bahasa Indonesia. Menurut model teori analisis Peirce, papan jabatan yang bertuliskan Chef dapat menjadi ikon yang lebih superior dibandingkan dengan tokoh perempuan yang ada pada ilustrasi diatas. Berbeda dengan tokoh perempuan yang tidak mendapatkan titel ataupun keterangan apapun mengenai statusnya dalam ilustrasi tersebut. Melihat papan jabatan Chef sangat ditegaskan, terlihat bahwa tokoh perempuan tersebut adalah bawahan dari pimpinan laki-laki tersebut. Pernyataan tersebut juga dapat didukung melalui gestur dari pimpinan perusahaan, yaitu berbicara sambil menunjukkan jari telunjuknya menggambarkan status antara seorang bos dengan karyawannya. Berdasarkan penjelasan mengenai kedudukan di antara pimpinan perusahaan dengan sosok perempuan terlihat bahwa tokoh laki-laki memiliki relasi kuasa yang lebih tinggi, sedangkan perempuan dalam ilustrasi kedua tidak mendapatkan atribut yang menunjukkan kehadirannya yang setara dengan tokoh laki-laki. Penggunaan unsur domestik seperti pel dan ember pembersih memunculkan stereotype perempuan akan fungsi domestiknya yang mengacu kepada kegiatan bersih-bersih.

Pertama-tama ilustrasi ini dianalisis berdasarkan model wacana kritis Sara Mills, dengan menggunakan dua tingkat posisi untuk dapat mengetahui bagaimana struktur dan makna ilustrasi secara keseluruhan. Pada tingkat subjek dan objek, dapat terlihat bahwa pimpinan perusahaan menempati posisi subjek dalam ilustrasi tersebut. Melalui kalimat yang diujarkan oleh pimpinan lakilaki, yaitu

\section{"Weltfrauentag war gestern.... ab heute konnen Sie wieder zeigen, was sie konnen"}

yang memiliki arti dalam bahasa Indonesia :
"Hari Perempuan Internasional sudah berlalu. Mulai sekarang Anda bisa menunjukkan, apa yang Anda mampu lakukan.”

diperlihatkan bahwa tokoh laki-laki memiliki kuasa yang dapat mengendalikan perilaku perempuan. Posisi perempuan sebagai objek yang dapat dikendalikan dalam ilustrasi kedua. Dalam ilustrasi ini, ilustrator terlihat lebih memihak kepada tokoh pimpinan laki-laki sehingga sosok perempuan masih dijadikan subordinat. Dalam tingkat posisi penulispembaca, penulis merujuk kepada ilustrator sebagai pembuat teks yang akan dianalisis, sedangkan posisi pembaca merujuk kepada saya sebagai penerima teks. Pada konsep pertama, penulis yang sekaligus sebagai penerima teks memposisikan diri sejajar sebagai tokoh perempuan. Perempuan dalam ilustrasi ini terlihat sibuk hanya dengan alat-alat domestik yang berhubungan dengan kegiatan bersihbersih. Berbeda dengan tokoh laki-laki yang hanya duduk di kursi dan menyuruh tokoh perempuan untuk melakukan sesuatu. Wacana yang berusaha disampaikan melalui media ilustrasi online ini cenderung menjadikan perempuan sebagai objek sehingga penggambaran perempuan akan tugas domestiknya, yaitu bersih-bersih semakin nyata terlihat.

Atribut-atribut yang terlihat pada teori segitiga semantik dilihat sebagai ikon atau tanda. Hal ini dapat terlihat dari pakaian yang digunakan oleh tokoh perempuan dan laki-laki dalam ilustrasi kedua. Atribut lain yang dilekatkan pada sosok perempuan berupa kain pel dan ember pembersih. Pertama tokoh perempuan memakai apron lengkap dengan sarung tangan bersih-bersih. Penggunaan apron sudah jelas merujuk kepada peran perempuan yang selalu memasak dan mengurus keperluan makan keluarganya, berbeda dengan pimpinan lakilaki yang menggunakan jas beserta dasinya yang menunjukkan bahwa laki-laki memiliki tugas yang untuk bekerja. Hal ini tentu menunjukkan relasi kuasa yang dimiliki laki-laki lebih kuat dibandingkan dengan perempuan dalam ilustrasi kedua. Kemudian melalui atribut yang melekat pada perempuan seperti sarung tangan pembersih, kain pel dan ember mampu menunjukkan bahwa perempuan memang terbiasa untuk melakukan kegiatan bersih-bersih.

Penggambaran perempuan dalam ilustrasi di atas dibentuk tidak hanya melalui tanda dan simbol, melainkan juga penggunaan warna dalam membangun wacana yang akan disampaikan. Warna dapat menjadi tanda bagaimana situasi yang 
dirasakan oleh kedua tokoh utama dalam ilustrasi di atas. Bila diperhatikan, warna yang menyelimuti atau berada di sekitar sosok perempuan berwarna hitam dan cenderung gelap. Hitam sering kali dikonotasikan sebagai hal yang negatif. Warna hitam dianggap kurang baik karena ditandai oleh tidak adanya cahaya dan karenanya dapat menunjukkan kegelapan, kesuraman dan kesedihan [15]. Kesan suram pada sosok perempuan diperkuat dengan raut muka sosok perempuan yang cenderung datar dan mengikuti perintah pimpinan laki-lakinya. Berbeda dengan warna-warna yang berada di sekitar pimpinan laki-laki seperti warna merah pada kursi dan warna terang pada bagian tengah ilustrasi sehingga seseorang dapat dengan jelas membaca papan jabatan bertuliskan Chef. Warna merah identik dengan keberanian dan kekuatan yang lebih besar dibandingkan orang lain. Hal ini sesuai dengan analisis yang dikatakan sebelumnya bahwa pimpinan laki-laki memiliki relasi kuasa yang lebih besar dibandingkan dengan sosok perempuan.

Selanjutnya bila dianalisis kembali kalimat yang diucapkan oleh pimpinan laki-laki pada ilustrasi kedua, yaitu :

\section{"Weltfrauentag war gestern.... ab heute konnen Sie wieder zeigen, was sie konnen"}

$$
\text { yang bila diterjemahkan dalam bahasa Indonesia }
$$
menjadi :

"Hari Perempuan Internasional sudah berlalu.. Mulai sekarang Anda bisa menunjukkan, apa yang Anda mampu lakukan."

Kalimat tersebut menunjukkan bahwa pimpinan laki-laki memberikan persetujuan untuk tokoh perempuan menunjukkan kemampuan yang dimilikinya. Namun bila melihat kembali, raut muka pimpinan laki-laki dalam ilustrasi kedua dapat terlihat raut yang cenderung pesimis terhadap kemampuan tokoh perempuan. Kemudian, kegiatan lain yang dimaksud oleh pimpinan laki-laki bukan seperti bekerja atau hal positif lainnya, akan tetapi masih berkaitan dengan tugas domestik seperti kegiatan bersih-bersih.

Selain itu, penyisipan kata Weltfrauentag juga menunjukkan bahwa pimpinan laki-laki menyadari akan adanya hari Perempuan Internasional. Meskipun demikian, kesadaran akan hari tersebut tidak cukup untuk mengubah pandangan pimpinan laki-laki terhadap status dan keberadaan tokoh perempuan. Pimpinan laki-laki cenderung pesimis terhadap apa saja hal yang dapat dilakukan oleh sosok perempuan.

Tabel 2. Alur analisa ilustrasi

\begin{tabular}{|c|c|c|}
\hline Tanda & Acuan Tanda & $\begin{array}{c}\text { Interpretasi } \\
\text { Makna }\end{array}$ \\
\hline $\begin{array}{l}\text { Papan jabatan } \\
\text { yang } \\
\text { bertuliskan } \\
\text { Chef dan } \\
\text { atribut jas } \\
\text { pada tokoh } \\
\text { laki laki. } \\
\text { Pengucapan } \\
\text { bahwa Hari } \\
\text { perempuan } \\
\text { Internasional } \\
\text { tela berlalu. }\end{array}$ & $\begin{array}{l}\text { Dapat menjadi } \\
\text { ikon yang } \\
\text { lebih superior } \\
\text { dibandingkan } \\
\text { dengan tokoh } \\
\text { perempuan } \\
\text { yang ada pada } \\
\text { ilustrasi diatas }\end{array}$ & $\begin{array}{l}\text { Bahwa posisi } \\
\text { laki-laki berada } \\
\text { di atas } \\
\text { perempuan. } \\
\text { Ucapan bahwa } \\
\text { hari perempuan } \\
\text { telah berlalu } \\
\text { menyiratkan } \\
\text { tidak ada lagi } \\
\text { harapan untuk } \\
\text { setara denganya } \\
\text { (menjadi } \\
\text { pimpinan), dan } \\
\text { hendaknya } \\
\text { perempuan } \\
\text { kembali } \\
\text { memperlihatkan } \\
\text { kemampuannya } \\
\text { dalam ranah } \\
\text { domestik }\end{array}$ \\
\hline $\begin{array}{l}\text { Atribut } \\
\text { pakaian } \\
\text { rumah, apron, } \\
\text { kain pel dan } \\
\text { ember }\end{array}$ & $\begin{array}{l}\text { Penggunaan } \\
\text { apron merujuk } \\
\text { kepada peran } \\
\text { perempuan } \\
\text { yang selalu } \\
\text { memasak dan } \\
\text { mengurus } \\
\text { keperluan } \\
\text { makan } \\
\text { keluarganya. } \\
\text { Pel dan ember } \\
\text { pembersih } \\
\text { memunculkan } \\
\text { stereotype } \\
\text { perempuan } \\
\text { akan fungsi } \\
\text { domestiknya } \\
\text { yang mengacu } \\
\text { kepada } \\
\text { kegiatan } \\
\text { bersih-bersih. }\end{array}$ & $\begin{array}{l}\text { Bahwa } \\
\text { perempuan } \\
\text { hanya layak } \\
\text { digambarkan } \\
\text { dalam posisinya } \\
\text { di ranah } \\
\text { domestik. }\end{array}$ \\
\hline $\begin{array}{l}\text { Warna gelap } \\
\text { dalam } \\
\text { ilustrasi }\end{array}$ & $\begin{array}{l}\text { Merujuk pada } \\
\text { suasana } \\
\text { mencekam } \\
\text { dan gelap } \\
\text { dalam } \\
\text { perdebatan } \\
\text { mengenai } \\
\text { peran dan }\end{array}$ & $\begin{array}{l}\text { Bahwa masa } \\
\text { depan kemajuan } \\
\text { perempuan } \\
\text { untuk bisa } \\
\text { setara seperti } \\
\text { laki-laki terlihat } \\
\text { suram. }\end{array}$ \\
\hline
\end{tabular}




\begin{tabular}{lll}
\hline Tanda & Acuan Tanda & $\begin{array}{c}\text { Interpretasi } \\
\text { Makna }\end{array}$ \\
\hline & $\begin{array}{l}\text { posisi } \\
\text { perempuan }\end{array}$ \\
\hline
\end{tabular}

\section{KESIMPULAN}

Berdasarkan analisis yang dilakukan pada kedua ilustrasi online dapat disimpulkan bahwa penggambaran perempuan dalam media baru berupa ilustrasi online di Jerman mengalami hambatan dengan tetap melekatkan unsur domestik yang kuat pada perempuan. Penggambaran perempuan dalam ilustrasi online pun tidak dapat dengan mudah dipisahkan unsur domestik (sapu, pel dan ember pembersih). Meski demikian terdapat perbedaan dalam menyikapi pelekatan unsur domestik ini. Ilustrasi pertama menunjukkan gambaran sosok perempuan yang bersifat positif. Hal ini dapat terlihat pada gambar ikon buku yang merujuk kepada wawasan atau pengetahuan dalam realitas sosial. Kemudian, warna dasar yang digunakan pada ilustrasi pertama cerah sehingga menimbulkan nuansa yang lebih baik. Berbeda dengan ilustrasi kedua yang justru masih menyampaikan wacana perempuan dengan fungsi domestiknya terutama mengurusi keperluan rumah tangga. Ilustrasi kedua masih menggambarkan tokoh perempuan dalam posisi subordinat, sedangkan tokoh laki-laki dalam posisi yang lebih dominan pada ilustrasi kedua. Kedua ilustrasi tersebut mengacu kepada realitas sosial saat ini bahwa perempuan saat ini sudah bisa mendapatkan pendidikan. Di sisi lain, perempuan masih juga dibebani oleh fungsi-fungsi domestik dalam konstruksi masyarakat sekarang. Dengan adanya nilai positif dan nilai negatif dalam penggambaran perempuan pada masa ini, dapat disimpulkan bahwa wacana gender yang mengusung tema kesetaraan perempuan terhadap laki-laki dalam bidang pendidikan dan pekerjaan masih saling bersaing untuk dapat diterima oleh khalayak umum. Selain itu, penulis media baru yang dalam jurnal ini merujuk kepada ilustrator dan medium yang digunakan khususnya media online juga ikut berperan aktif dalam memposisikan penggambaran dan perubahan pada wacana terhadap perempuan dalam masyarakat.

\section{REFERENSI}

[1] A. Rokhmansyah, Pengantar Gender dan Feminisme: Pemahaman Awal Kritik Sastra Feminisme, Yogyakarta: Garudawacha, 2016.
[2] K. Pittner, "Die Hausfrau und der Kiichenprofi-Die Entwicklung von Genderstereotypen in der Haushaltswerbung," Zeitschrift Fur Angewandte Linguistik, vol. 61, no. 1, 2014.

[3] H. Pasuhuk, "Sekilas Tentang Sistem Pemilu di Jerman," Deutsche Welle, 9 Juni 2017. [Online]. Available: https://www.dw.com/id/ sekilas-tentang-sistem-pemilu-di-jerman/a39181144. [Diakses 19 November 2018].

[4] Center for Strategic and Internasional Studies (CSIS), Penulis, Orientasi Sosial, Ekonomi dan Politik Generasi Milenial. [Performance]. Center for Strategic and Internasional Studies (CSIS), 2017.

[5] KBBI Daring, "Media," [Online]. Available: https://kbbi.web.id/media. [Diakses 18 November 2018].

[6] S. Jaworska dan R. Krishnamurthy, "On the F word: A corpus-based analysis of the media representation of feminism in British and German press discourse, 1990-2009," SAGE Journals, vol. 23, no. 4, pp. 401-431, 2012.

[7] E. D. S. Watie, "Representasi Wanita Dalam Media Massa Massa Kini," The Messenger, vol. II, no. 2, 2010.

[8] Toon Agent, [Online]. Available: https://de.toonpool.com/toonagent/. [Diakses 22 Desember 2018].

[9] S. Endraswara, Metodologi Penelitian Sastra, Yogyakarta: 2008, 2008.

[10] M. Fakih, Analisis Gender \& Transformasi Sosial, Yogyakarta: Pustaka Pelajar, 2001.

[11] Eriyanto, Analisis Wacana: Pengantar Analisis Teks MEdia, Yogyakarta: LkiS, 2001.

[12] H.-L. L. Chang, "semiotics," The University of Chicago, 2007. [Online]. Available: https://csmt.uchicago.edu/glossary2004/semi otics.htm. [Diakses 01 Agustus 2019].

[13] S. W. Littlejohn dan K. A. Foss, Theories of Human Communication. 10 thn Edition, Wafeland Press, 2011.

[14] M. Gottfried, "Am 8. März ist Weltfrauentag," ce-comico.de, [Online]. Available: http://www.paramantus.net/am-8marz-ist-weltfrauentag.

[15] M. Brenner, Informatonen zur politischen Bildungm Nr. 301: Familie und Familienpolitik, Bonn: STARK Druck GmbH+Co. KG, 2008.

[16] I. A. Putri, "Hardiness Pada Ibu Bekerja. [Thesis]," Universitas Muhammadiyah Surakarta, Surakarta, 2017. 
[17] Y. Sain, "Analisis Semiotika pada Artikel "The Connotations of English Colour Terms: Colour-based X-phemisms (Keith Allan)," Universitas Hasanudin, Makasar, 2018.

[18] K Koufogiorgos, "Weltfrauentag," 23 Maret 2016. [Online]. Available: https://www.toonpool.com/toonagent/showi mage? imageid $=162303 \&$ offset $=-$ $1 \&$ popup $=1$.
[19] K. Koufogiorgos, "Biografi Koufogiorgos," [Online]. Available: http:http://www. koufogiorgos.de/lebenslauf_index.html. [Diakses 14 Desember 2018]. 